http://doi.org/10.35784/iapgos.932

\title{
ANALYSIS OF THE ELECTRICITY METERING SYSTEM FOR OWN ELECTRIC SUBSTATION NEEDS
}

\author{
Sergiy Stets, Andriy Stets \\ National University of Water and Environmental Engineering Institute of Automatics, Cybernetics and Computer Engineering, Rivne, Ukraine
}

Abstract. In the article the researches of the use of electronic meters with standard nominal parameters for metering of substation own electric energy in the schemes of high and low voltage networks simultaneously with the use of the corresponding calculated coefficients on voltage for the purpose of operational control and determination of the reliability of measurement of electricity parameters.

Keywords: electricity metering, meter, electrical substation

\section{ANALIZA SYSTEMU POMIAROWEGO ENERGII ELEKTRYCZNEJ NA POTRZEBY WLASNE STACJI ELEKTROENERGETYCZNEJ}

\begin{abstract}
Streszczenie. W artykule przedstawiono badania wykorzystania liczników elektronicznych o standardowych parametrach nominalnych do pomiaru energii elektrycznej własnej stacji elektroenergetycznej w obwodach wysokiego i niskiego napięcia przy jednoczesnym zastosowaniu odpowiednich obliczonych współczynników napięciowych dla potrzeb sterowania praca i określania wiarygodności pomiaru parametrów elektrycznych.
\end{abstract}

Słowa kluczowe: pomiar energii elektrycznej, licznik, podstacja elektryczna

\section{Introduction}

The main areas of modern electricity development are infrastructure improvement, digital layer overlay, and business process modernization during power generation, transmission, distribution, supply and use, as defined by the Smart Grid concept.

Central to solving these problems in the Smart Grid concept is provided by Smart Meters and based on them Smart Metering Systems, which in Ukraine traditionally refer to an automated commercial electricity metering system.

With the creation of the Wholesale Electricity Market of Ukraine, where differentiation of electricity metering is carried out on an hourly basis, and its calculations are made on a daily basis, automated systems of commercial metering of electricity have become the basic tool for determining the volume of electricity sales. The 21 st century is characterized by the mass introduction and integration of automated commercial electricity metering systems into a distributed hierarchical commercial metering system of the Wholesale Electricity Market of Ukraine. Since 2016, calculations on the Wholesale Electricity Market of Ukraine have been made entirely on the basis of the displays of automated systems of commercial metering of electricity.

In the conditions of liberalization of the electricity market, automated systems of control, metering and management of energy use are almost crucial in solving the problems of increasing the efficiency of generation, transmission, distribution and use of electricity. Only with the application of highly reliable full-scale multifunctional automated systems of commercial metering of electricity of energy market entities that co-ordinate in a single information system and provide solutions for demand management and market calculations, in particular, based on the cost of ancillary services, to improve the efficiency of electricity use by end consumers.

The gradual transition of the wholesale electricity market of Ukraine from the "single buyer" market model to the liberalized electricity market $[1,3,6]$ will require the formation of appropriate information support for electricity billing. These are fundamentally new approaches to the definition of commercial metering data in a context where the price of electricity consists of the prices of a certain range of electricity products and the value of ancillary services, first of all, of balancing the market, which are sold and bought within the market. Under these conditions, fundamentally new requirements for hardware and software, which form data for electricity billing, as well as for the rules for their construction, implementation and application, are put forward.

To reduce the technological costs of electricity, it is important to mattering and analyze electricity consumption for own needs. According to the sectoral guidance document (SGD) "Electricity expenditure for own and economic needs of power station and networks" the mattering of electricity consumed for own needs of substations must be carried out by separate metering devices. Usually, inductive three-phase, two- or three-element (depending on the type of network of the given voltage level) meters of active electricity are used. The relevance of the introduction of automated electricity metering systems at the substations in accordance with the requirements of the Concept of construction of automated electricity metering systems in the conditions of the energy market within the automated dispatching control systems, implies the use of modern multifunctional electronic electricity meters. The automated dispatching system is assembled on-site from mass-produced measuring equipment and has standard technical parameters [2].

\section{The aim and objectives of the study}

Most substations have electricity metering for a three-element, high-voltage network $(35 / 10(6) \mathrm{kV})$, i.e. meters are supplied with a secondary voltage of $100 \mathrm{~V}$ from the measuring transformer. An exception is the mattering for electricity for own needs, which is carried out by meters for three or four-wire low voltage network on the side of $0.4(0.23) \mathrm{kV}$ own transformers. In this regard, the introduction of automated control systems containing microprocessor-based measuring equipment in the form of electronic meters raises the question of the possibility of using these meters to mattering for the electricity of a three-wire highvoltage network also for the mattering of low-voltage electricity $0.4(0.23) \mathrm{kV}$ used for the substation's own needs and operational control of its parameters.

The transition to the use of automated commercial metering systems in conjunction with automated dispatching systems is the most promising avenue for their development, as these systems are interoperable in terms of operational control over power consumption and capacity. At the same time, the automated system at each level provides for the use of a wide range of unified software using microprocessor technologies. For such a measuring complex, the main technical task is to collect data from electronic meters along the information lines. However, the question remains as to the possibility of applying and unifying types of meters with the same technical parameters at the local substation level (as measuring equipment within the automated control system) in the presence of connections of different voltage class: $35 / 10(6) \mathrm{kV}$ high-voltage switches and own needs. $0.4(0.23) \mathrm{kV}$.

It is known that high-voltage metering points on the highvoltage side of $35 / 10(6) \mathrm{kV}$ are installed at the substations for consumer switches, and low-voltage metering points are only on the side of $0.4(0.23) \mathrm{kV}$ of the transformers of own needs for 
metering of electricity consumed on their own substation needs. These metering points are equipped with induction meters, which must be replaced by electronic ones when implementing automated systems. Multifunctional electrical meters on the highvoltage side are programmable electronic devices that have a flexible metering system that is customizable by software such as the Astaris SL7000 Smart or ZMD400AR/CR + ZFD400AR/CR Landis+Gyr Dialog. These meters can be programmed to operate in three- or four-wire high or low voltage networks, for direct or transformer start-up, and can be used as part of automated commercial metering systems. At $110(35) / 10(6) \mathrm{kV}$ substations, high-voltage metering points are generally not commercial, i.e. they serve for technical mattering $[4,5]$.

Low-voltage mattering of own needs is used both to control the consumption of electricity for own needs, as well as to analyze the balance and its technological costs for transmission by electrical networks. Accordingly, an automated electricity metering system within an automated dispatching system that implements the function of operational control of electricity and power need not be commercial. Therefore, the use of the above electronic devices intended for high voltage metering with a flexible metering system as a measuring technique within an automated control system is not always appropriate, given their high cost.

For the automated electricity metering system within the automated control system, for the purpose of high-voltage metering, the same type of multifunctional electronic meters are used for a three-wire high-voltage network without a flexible metering system (for example, NR-03 ADDED0.Z-U) with standard technical parameters protocol of information exchange, the voltage circuits of which are calculated for the nominal secondary voltage $3 \times 57.7 / 100 \mathrm{~V}$. The function of operational control and analysis is implemented power consumption in highswitches, but does not solve the problem of keeping those same counters electricity consumed for own needs substations on the low side of $0.4(0.23) \mathrm{kV}$ transformers own needs.

Because modern multifunction meters have a flexible measuring system, which can be parameterized, it is logical to assume that electronic meters with standard nominal parameters can be used in the schemes of high and low voltage networks, subject to certain conditions and by applying the corresponding voltage coefficients [5]. Given the impossibility or impracticality of using these meters as part of an automated control system, the task is to research the possibility of using microprocessor-based measuring equipment in the form of electronic meters with standard technical characteristics for the mattering of electricity as a whole, consumed as a high power consumed substation needs at low voltage.

\section{Solving the problem}

The main purpose of the research is to find out the possibility of solving this problem in the technical plan, namely to research the reliability of metering of electricity (power) consumed for own needs on the side of $0.4(0.23) \mathrm{kV}$ own transformer $10(6) / 0.4(0.23) \mathrm{kV}$, electronic meters with a nominal voltage of $3 \times 57.7 / 100 \mathrm{~V}$ taking into mattering the corresponding design factor.

In the implementation of automated dispatching control system at the substations high-voltage switches as microprocessorbased measuring equipment for measurement (accumulation) and data transmission use electronic multifunctional three-element electricity meters NP-03 ADDED0,3-U. $3 \times 57.7 / 100$ V. For the purpose of research, these meters were also installed at the points of mattering of own needs on the side of $0.4(0.23) \mathrm{kV}$. The use of three-element electronic meters instead of two-element inductors made it possible to record not only in the three-wire $0.23 \mathrm{kV}$ network but also in the four-wire $0.4 \mathrm{kV}$ network of own needs, where electricity consumption can occur each phase separately, requiring the presence of three measuring transformers, and three items in the counter.

To mattering for the needs of the voltage circuits of the NP-03 model meters, a secondary voltage of $100 \mathrm{~V}$ was supplied from the measuring transformers of the voltage, and the phasing was carried out so that the vector of the secondary linear voltage of the measuring transformer coincided with the corresponding linear voltage of $0.4(0.23) \mathrm{kV}$ from the transformer own needs. Since the winding of the higher voltage of the measuring voltage transformer is connected to the star and the lower voltage to the star with the output zero point, the angle of displacement between the vectors of the linear voltages of the windings of the higher and lower voltage is zero. This connection group of the measuring transformer of the voltage transformer coincided with the group of connection of the transformer of own needs $10(6) / 0.4 \mathrm{kV}$ on the low side. The lower voltage winding of the $10(6) / 0.23 \mathrm{kV}$ selfcontained transformer is connected in a "triangle", therefore, depending on the winding performance, an angular displacement may occur between the higher voltage and lower voltage linear vectors. For a three-wire, $0.23 \mathrm{kV}$ power supply system using two current transformers, the connection of three-element meters to the metering scheme was made by connecting the current circuit of the middle element of the meter to the sum of the currents of phases $\mathrm{A}$ and $\mathrm{C}$ with reverse polarity. For the $0.4 \mathrm{kV}$ four-wire network, where three current transformers are used, all three meter elements were connected. It should be noted that the technical decision on the reorganization of the specified metering points cannot be fulfilled if $0.4(0.23) \mathrm{kV}$ direct-inductionmeters are used in the schemes, since electronic transformer-based meters are rated at $3 \times 57.7 / 100 \mathrm{~V}$ and current $3 \times 5 \mathrm{~A}$ cannot be incorporated directly into the scheme, i.e. without the use of separate circuits of current and voltage. Therefore, in the technical plan we have a scheme of semi-direct switching with the use for the circuits of the counter voltage, which corresponds to its technical parameters [6].

After the determination of $0.4(0.23) \mathrm{kV}$ of the transformer of own needs, from the metering points of electricity consumed by the substation for own needs, from the digital interfaces of the HP-03 meters, separate parameters of the electrical network were taken out with the help of the appropriate software reliability of the measuring system as a whole. For convenience, the instantaneous values of the parameters recorded by the meters in the secondary circuits of the measuring current and voltage transformers for each phase were taken separately, without the use of calculated coefficients.

Measurement data obtained with the software from the substation meters are given in Table 1 .

The results obtained show that the secondary circuits of the meters are powered by a voltage of $100 \mathrm{~V}$ from the measuring transformers of the voltage, and since the information was read from the interface of the three-element meter, we have, on all counting points, an average phase voltage of about $60 \mathrm{~V}$ (nominal phase voltage of the counter is $57.7 \mathrm{~V}$ ). It should be noted that the load of some current collectors is reactive. As you can see, when consuming electricity for the substation's own needs with a linear voltage of $0.4 \mathrm{kV}$, there may be a situation where the load is asymmetrical and connected to only two (one) phases of the fourwire network, and in the other one (two) phase the load current is absent. In this three-phase metering scheme, three measuring current transformers are used and current circuits are connected to the star, so in the absence of load current in one of the phases in the zero wire, the unbalance current flows, and the three-element counter conducts a phase analysis of the power supply parameters in the loaded phases. In contrast to the $0.4 \mathrm{kV}$ four-wire network, two measuring current transformers are used for the three-wire $0.23 \mathrm{kV}$ network, the current circuits of which are connected in "incomplete star" and the zero pole connected to the middle element of the counter with reverse polarity. the sum of currents of phases $\mathrm{A}$ and $\mathrm{C}$ flows. 
Table 1. The results of the phase measurements of the parameters of the power network of own needs

\begin{tabular}{|c|c|c|c|c|c|c|c|c|c|c|c|c|}
\hline \multirow{2}{*}{ \# of substation } & \multicolumn{3}{|c|}{ Voltage TV by phases $\mathrm{U}_{\mathrm{f}}, \mathrm{V}$} & \multicolumn{3}{|c|}{ Amperage by phases $\mathrm{I}_{\mathrm{f}}, \mathrm{A}$} & \multicolumn{3}{|c|}{ Active power $\mathrm{P}_{\mathrm{f}}, \mathrm{W}$} & \multicolumn{3}{|c|}{ Reactive power $\mathrm{Q}_{\mathrm{f}}, \mathrm{VAr}$} \\
\hline & «A» & «B» & $« \mathrm{C} »$ & «A» & «B» & «C» & «A» & $« \mathrm{~B} »$ & «C» & «A» & «B» & «C» \\
\hline \multicolumn{13}{|c|}{ Mattering points on the low side of own needs with a linear voltage of $0,4 \mathrm{kV}$} \\
\hline 1 & 60.7 & 61.2 & 61.0 & 0.8 & 0.1 & 0 & 48.6 & 7.0 & 2.4 & 3.6 & 3.3 & -0.3 \\
\hline 2 & 62.6 & 63.1 & 63.1 & 0 & 0.3 & 0.1 & 0 & 19.9 & 5.1 & 0 & 0 & 5.8 \\
\hline 3 & 62.4 & 62.7 & 62.3 & 0.1 & 0.3 & 0.6 & 8.6 & 18.2 & 35.5 & 0 & 0 & 0 \\
\hline 4 & 60.0 & 60.0 & 59.6 & 0 & 1.4 & 0.3 & 2.2 & 82.6 & 10.0 & 0.5 & 6.1 & 15.1 \\
\hline \multicolumn{13}{|c|}{ Metering points on the low side of own needs with a linear voltage of $0,23 \mathrm{kV}$} \\
\hline 5 & 59.9 & 59.1 & 59.0 & 0.6 & 0.7 & 0.7 & 30.3 & 38.4 & 34.1 & 15.8 & 15.1 & 22.1 \\
\hline 6 & 60.1 & 60.1 & 59.3 & 1.3 & 1.5 & 1.5 & 74.8 & 87.2 & 86.6 & 10.5 & 2.4 & 17.5 \\
\hline 7 & 59.2 & 59.7 & 59.2 & 0.2 & 0.1 & 0.1 & 1.8 & -0.9 & 3.0 & 10.3 & 7.4 & 6.5 \\
\hline 8 & 59.7 & 59.2 & 59.9 & 0 & 0.1 & 0.1 & 2.8 & 7.4 & 4.9 & 0 & 0 & 4.2 \\
\hline 9 & 61.9 & 61.8 & 61.7 & 1.6 & 1.8 & 1.4 & 95.9 & 108.3 & 82.7 & -10 & 10.8 & 10.6 \\
\hline
\end{tabular}

Accordingly, in the asymmetric nature of the load, i.e. in the absence of current in one of the phases, due to the asymmetry, the vector diagram of currents and the total active power of the network (as well as reactive) will be unreliable. From the received data it is clear that only with symmetrical nature of the load can the most reliable data be obtained while mattering for the electrical parameters of the network.

The analysis of the work of the reorganized metering points as external measuring devices within the automated control system "SCADA IMS" occurred after reading the electrical parameters obtained at the lower level of the substations of the district network from the RS-485 interfaces via the RTU-560 output buffer Modbus information. Since the process of obtaining this information is automated and consists of recording data from electricity meters throughout the mattering period, it is important to analyze the reliability of the measurement information, as well as the synchronicity of measurements at the metering points. It should be borne in mind that in the reports of the most automated control system, the read data is time-bound and contains the real values (unlike the data in Table 1), that is, they take into mattering all the calculated current and voltage factors, related to the mattering of the parameters of the mains through measuring current transformers and measuring transformers of voltage. $\mathrm{I}_{\mathrm{f}}$ the meters are connected to voltage transformers and current transformers (transformer switching), when determining electricity consumption (power) according to their readings, it is necessary to use the calculated coefficient, which takes into mattering the transformation coefficients of these measuring transformers:

$$
\mathrm{K}_{\mathrm{p}}=\frac{\mathrm{U}_{1}}{\mathrm{U}_{2}} \times \frac{\mathrm{I}_{1}}{\mathrm{I}_{2}}=\mathrm{K}_{\mathrm{U}} \times \mathrm{K}_{\mathrm{I}}
$$

where $\mathrm{U}_{1}, \mathrm{U}_{2}$ is the rated voltage of the primary and secondary windings of the measuring voltage transformer, respectively; $\mathrm{I}_{1}, \mathrm{I}_{2}$ is the rated current of the primary and secondary windings of the measuring current transformer, respectively, A.

In this case, after reorganization of the points of mattering of own needs on the side of $0.4(0.23) \mathrm{kV}$, it should be taken into mattering that instead of the nominal voltage $\mathrm{U}_{\text {nom }}=400(230) \mathrm{V}$. In own needs the secondary voltage $\mathrm{U}_{2}=100 \mathrm{~V}$ from the measuring transformer is supplied voltages, and the nominal parameters of the low-voltage measuring current transformers and the transformation factor in the power network did not change. Since the metering needs to be reduced to $0.4(0.23) \mathrm{kV}$, formula (1) takes on a slightly different form:

$$
\mathrm{K}_{\mathrm{p}}=\frac{\mathrm{U}_{1}^{\prime \prime}}{\mathrm{U}_{2}} \times \frac{\mathrm{I}_{1}}{\mathrm{I}_{2}}=\mathrm{K}_{\mathrm{U}}^{\prime \prime} \times \mathrm{K}_{\mathrm{I}}
$$

where $\mathrm{U}_{1}$ - nominal voltage of the transformer, $\mathrm{V}$.

Electricity consumption can be determined by integrating power over time, so information from an automated dispatching system regarding load schedules for reorganized metering points used for own needs was used for convenience. Moreover, in the reports of the automated control system, the primary values of the network parameters (current, power) were obtained, that is, taking into mattering the calculated coefficients.

The substation's own energy sources include mainly current collectors that provide heating and lighting for the equipment. Therefore, to simplify the calculations, it is conventionally assumed that the power factor is equal to one and the phase voltage is the same for each phase, i.e. $U_{\mathrm{f}}=\mathrm{U}_{\mathrm{A}}=\mathrm{U}_{\mathrm{B}}=\mathrm{U}_{\mathrm{C}}$. In addition, the reorganization of the metering points of the transformation needs the transformation factor of the measuring current transformers does not change, and a new voltage factor $\mathrm{K}_{\mathrm{U}}$ is introduced. the sum of the capacities of the individual phases, taking into mattering the calculated coefficient (3).

Since the automated dispatching system in the automatic mode controls the condition of the equipment and the modes of consumption, an important criterion is the promptness of obtaining information. Accordingly, in addition to averaged values of currents and capacities, instantaneous values were used to analyze the measurement results, which reflected the operational situation directly in real time on the layout of a substation. For the purpose of comparative analysis of the data received from the automated system of dispatching data management and real parameters of the grid, the calculations were performed according to the formula. All results of measurements in the automated control system and calculations for individual substations of district grids are given in Table 2.

As we can see, for a power supply network with a voltage of $0.4(0.23) \mathrm{kV}$, the load is asymmetrical. In this case, averaged over a certain period of time, data (both current and power) differ little from the instantaneous values, that is, we have a uniform load schedule for electrical equipment of our own needs. Basically, the data obtained from the automated control system of the threephase power network are close to the calculated values (the largest difference is $0.5 \mathrm{~kW}$ ). For Substation \#7 we have an unreliable value of active power, which may be due to the non-observance of the above conditions of ensuring the reliability of the data of the metering of electricity consumed for own needs of the substation.

$\mathrm{P}=\mathrm{K}_{\mathrm{p}}\left(\mathrm{P}_{\mathrm{A}}+\mathrm{P}_{\mathrm{B}}+\mathrm{P}_{\mathrm{C}}\right)=\mathrm{K}_{\mathrm{P}}\left(\mathrm{U}_{\mathrm{A}} \mathrm{I}_{\mathrm{A}} \mathrm{K}_{\mathrm{I}} \cos \varphi_{\mathrm{A}}+\mathrm{U}_{\mathrm{B}} \mathrm{I}_{\mathrm{B}} \mathrm{K}_{\mathrm{I}} \cos \varphi_{\mathrm{B}}+\right.$

$\left.\mathrm{U}_{\mathrm{C}} \mathrm{I}_{\mathrm{C}} \mathrm{K}_{\mathrm{I}} \cos \varphi_{\mathrm{C}}\right)=\mathrm{K}_{\mathrm{U}}^{\prime \prime} \mathrm{U}_{\mathrm{f}}\left(\mathrm{I}_{\mathrm{A}}+\mathrm{I}_{\mathrm{B}}+\mathrm{I}_{\mathrm{C}}\right)$

where $\mathrm{K}_{\mathrm{U}}$ - coefficient taking into mattering the use of measuring equipment voltage $3 \times 57.7 / 100 \mathrm{~V}$ in the network voltage $400(230) \mathrm{V} ; \mathrm{U}_{\mathrm{f}}-$ phase voltage measured by the meter, $\mathrm{V} ; \mathrm{I}_{\mathrm{A}}, \mathrm{I}_{\mathrm{B}}$, $\mathrm{I}_{\mathrm{C}}$ are the primary values of currents (taking into mattering the transformation factor of measuring current transformers) for each phase, respectively, A. 
Table. 2. The results of measurements of the parameters of the power network of substations' own needs in the automated control system

\begin{tabular}{|c|c|c|c|c|c|c|c|c|c|}
\hline \multirow{4}{*}{ \# of substation } & \multicolumn{2}{|c|}{ Transformation factor } & \multicolumn{6}{|c|}{ Measured values in an automated dispatching control system } & \multirow{4}{*}{$\begin{array}{c}\text { Estimated value } \\
\Sigma \mathrm{P}, \mathrm{kW}\end{array}$} \\
\hline & \multirow{3}{*}{$\mathrm{K}_{\mathrm{U}}^{\prime \prime}$} & \multirow{3}{*}{$\mathrm{K}_{\mathrm{I}}$} & \multicolumn{4}{|c|}{ Instant } & \multicolumn{2}{|c|}{$\begin{array}{c}\text { Averaged over an interval of } 30 \\
\text { minutes }\end{array}$} & \\
\hline & & & \multicolumn{3}{|c|}{ Amperage $\mathrm{I}_{\text {nom }}, \mathrm{A}$} & \multirow{2}{*}{$\Sigma \mathrm{P}, \mathrm{kW}$} & $\mathrm{I}_{\text {nom }}, \mathrm{A}$ & \multirow{2}{*}{$\Sigma \mathrm{P}, \mathrm{kW}$} & \\
\hline & & & Phase A & Phase B & Phase C & & Phase B & & \\
\hline 1 & $230 / 100$ & $150 / 5$ & 40.2 & 30.3 & 22.2 & 12.85 & 30.2 & 12.76 & 12.3 \\
\hline 2 & $230 / 100$ & $200 / 5$ & 43.4 & 26.7 & 34.7 & 12.75 & 26.6 & 12.48 & 13.9 \\
\hline 3 & $230 / 100$ & $200 / 5$ & 29.1 & 26.1 & 46.6 & 11.07 & 26.1 & 10.90 & 13.5 \\
\hline 4 & $230 / 100$ & $150 / 5$ & 27.8 & 13.7 & 18.9 & 7.75 & 13.6 & 7.71 & 8.0 \\
\hline 5 & $400 / 100$ & $100 / 5$ & 11.6 & 16.3 & 11.5 & 9.38 & 15.6 & 9.6 & 9.1 \\
\hline 6 & $230 / 100$ & $600 / 5$ & 56.5 & 41.5 & 81.6 & 23.6 & 41.0 & 23.14 & 23.8 \\
\hline 7 & $230 / 100$ & $200 / 5$ & 31.6 & 42.2 & 42.4 & 0.07 & 41.9 & 0.03 & 15.4 \\
\hline 8 & $230 / 100$ & $300 / 5$ & 20.7 & 26.2 & 12.7 & 7.98 & 29.2 & 8.94 & 7.9 \\
\hline \multirow{2}{*}{9} & $400 / 100$ & $400 / 5$ & 54.1 & 70.4 & 46.4 & 40.64 & 70.6 & 40.68 & 39.4 \\
\hline & $400 / 100$ & $400 / 5$ & 0.8 & 1.3 & 1.0 & 0.47 & 1.24 & 0.46 & 0.72 \\
\hline 11 & $400 / 100$ & $50 / 5$ & 14.2 & 20.1 & 8.8 & 10.39 & 20.0 & 10.29 & 9.9 \\
\hline 12 & $400 / 100$ & $50 / 5$ & 11.9 & 0 & 15.0 & 6.40 & 0 & 6.34 & 6.2 \\
\hline 13 & $230 / 100$ & $100 / 5$ & 7.3 & 9.5 & 6.0 & 5.31 & 9.4 & 5.26 & 3.0 \\
\hline 14 & $230 / 100$ & $50 / 5$ & 13.3 & 14.7 & 5.9 & 4.43 & 16.2 & 4.78 & 4.5 \\
\hline
\end{tabular}

\section{Conclusions}

Analyzing the results of the studies, we can conclude:

- mattering of the electricity of own needs on the side of $0.4(0.23) \mathrm{kV}$ by inclusion in the measurement scheme of electronic meters with a nominal voltage of $100 \mathrm{~V}$ is possible solely for the purpose of operational control of the parameters of active electricity, if the use of meters with a flexible system of measurement is impossible or impractical:

- the real values of the electricity parameters can be determined by a factor that takes into mattering the fact that the meters at a voltage of $100 \mathrm{~V}$ in the network with a voltage of $400(230)$ $\mathrm{V}$;

- if the metering of the electricity consumed for the substation's own needs is carried out by direct switches, the mattering of own needs by electronic meters with a rated voltage of $100 \mathrm{~V}$ on the side of $0.4(0.23) \mathrm{kV}$ is impossible;

- for reliable and accurate operational control of electricity parameters at any load nature, in the presence of measuring equipment in the automated control system of only electronic meters with a rated voltage of $100 \mathrm{~V}$, it is necessary to consider the possibility of mattering on the high side $10(6) \mathrm{kV}$ of the transformer of own needs;

- only three-element multifunctional electronic meters should be used as a measuring equipment for the automated control system as a means of measuring equipment on the side of $0.4(0.23) \mathrm{kV}$;

- in the case of unbalanced load mode, the obtained values of the parameters of the reactive electricity will be unreliable;

- to ensure the accuracy of mattering and operational control of the parameters of electricity, the following conditions must be observed: self-contained transformers and voltage transformers connected to the same bus section must be used; self-contained transformers and voltage measuring transformers must have the same connection group (allow for angular displacement of vectors); the load of own needs should be evenly distributed across all phases.

\section{References}

[1] Chauhan et al.: Real Time Energy Management System for Smart Buildings to Minimize the Electricity Bill. International Journal of Emerging Electric Powe Systems 18(3), 2018, 1-15.

[2] Kaplan C.E.: Simplified Model and Genetic Algorithm Based Simulated Annealing Approach for Excitation Current Estimation of Synchronous Motor. Advances in electrical and computer engineering 18(4), 2018, 75-84.

[3] Lakrih S., Diouri J.: Combined Frequency Equivalent Model for Power Transmission Network Dynamic Behavior Analysis. International Journal of Emerging Electric Power Systems 19(2), 2018, 20170104

[4] Popkov D.M., Lunyaka A.V, Krzhevytskyi V.S.: Implementation of Automated Electrical Accounting and Control Systems in the Example of Odesaoblenergo. Collection of scientific works Odessa National Academy of Food Technologies 53(3)/2017, 45-48.

[5] Scrabets F.P.: Electricity Supply: Tutorial. NSU 2015.

[6] Zhao W.Ye., et al.: A Grouping Strategy Based on Prime Factorization for Capacitor Voltage Balancing of the Modular Multilevel Converter, 2018, 570580 .

\section{Ph.D. Serhiy Stets}

e-mail: s.e.stets@nuwm.edu.ua

Associate professor of the Department of Automation, Electrical and Computer Integrated Technologies of National University of Water and Environmental Engineering. The basic directions of scientific work are: automation of systems of measurement and control of technological processes, development and research of mathematical models of objects and systems of automatic control, development and research of automated systems of management of hydro-mining of minerals and soil moisture.

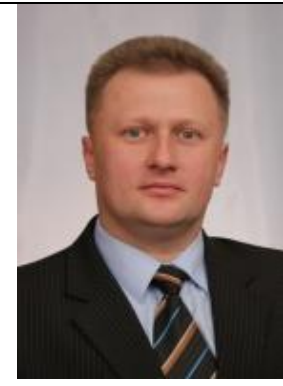

http://orcid.org/0000-0003-0063-5009

\section{B.Sc. Andii Stets}

e-mail: stets_ak19@nuwm.edu.ua

Student of Department of Applied Mathematics of National University of Water and Environmental Engineering.

The main area of scientific work is the development, programming and research of mathematical models of objects and systems of automatic control.

http://orcid.org/0000-0002-8271-647X

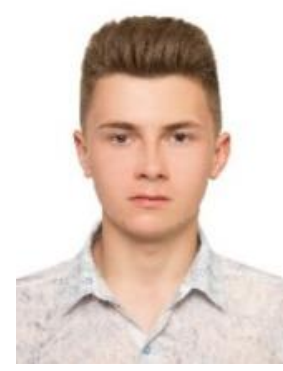

otrzymano/received: 22.12 .2019

przyjęto do druku/accepted: 26.06 .2020 